\title{
A GLOBAL ONLINE CONTENT QUALITY CHECK SOLUTION
}

\author{
Uyiosa Omoregie \\ Kirsti Ryall
}

Avram Turing, Guelph, ON, Canada.

Email contact: Uyiosa.omoregie@avramturing.com 
October 2020

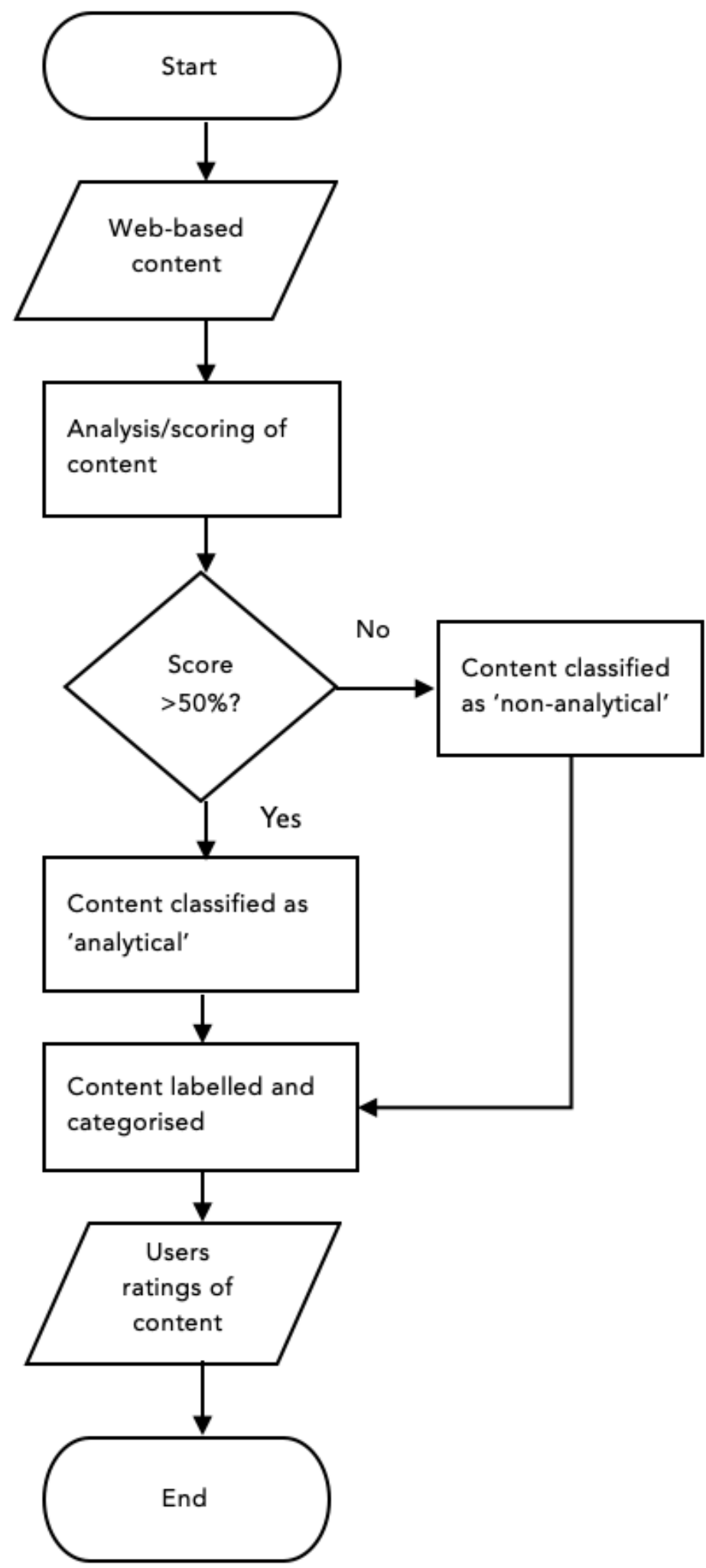

Figure 1: The global online analytical check flowchart 